\title{
The Reality and Image of the Prophet according to the Theologian and Poet 'Abd al-Ghanī al-Nābulusī
}

\author{
Samuela Pagani
}

Bright moons have spoken from darkest nights -

'Tell those who burn with desire:

For all who love Muhammad, sleep is forbidden!'

Qālat aqmāru al-dayājī - qul li-arbābi al-gharām kullu man yashaq Muḥammad - yanbaghī an lā-yanām ${ }^{1}$

On the night of 25 Sha'bān 1324 (14 October 19o6), the pious scholar, Ottoman poet, and judge Yūsuf ibn Ismāīl al-Nabhānī, who was born in Palestine in 1265/1849 and died in Beirut in 1350/1932, saw 'Abd al-Ghanī al-Nābulusī, who had died two centuries before, in a dream; they had a pleasant conversation. The following morning Nabhānī had forgotten what they had discussed, but rejoiced nevertheless, because, he said, Nābulusī

is one of the greatest gnostic saints and the imam of practising scholars. His way of bringing together (jam') the sciences of the apparent and the hidden ('ulūm al-zāahir w-al-bātin) is unmatched among all the authors I know of who, from his day to our own, have surpassed themselves in knowledge and gnosis. From him one can gain a great deal in all the sciences, especially those that concern religion (din), the unicity of God (tawhìd), divine gnosis (al-márifa bi-lläh), and the exaltation of the rank

1 Muwashshaḥ by Nābulusī, reproduced in Nabhānī, al-Majmū̃a al-Nabhāniyya, 4: 40o. Heard on 4 November 2018 in Marrakech, at the concert to which the organisers of the conference invited its speakers. Many thanks to them. 
('uluww qadr) of the Lord of Messengers, may God bless him and bring him peace. ${ }^{2}$

In this passage, the "exaltation of the rank" of Muhammad is presented as a domain of the religious sciences in its own right. At the beginning of the twentieth century Nabhānī published two monumental anthologies of prose texts and poems honouring the Prophet (madäih), mostly by Mamluk and Ottoman authors who wrote in Arabic, but weren't necessarily Arabs. ${ }^{3}$ Their variety gives the reader some idea of the importance of the veneration of the Prophet in the study of Islamic cultural and religious history during these periods. Nabhān's anthologies invite us to rethink the historiographical categories and definitions of identity that have become standard in the contemporary period. The glorification of the Prophet defies all such divisions because it links theology and ritual, metaphysics and poetry, jurisprudence and Sufism, occurring in a wide variety of genres and registers, from erudite commentary to accounts of the miraculous birth of the Prophet (mawlid), from qașāid full of the figures of style prized by scholars to strophic poems (muwashshahạa tand mawāliyā) sung at festivals and dhikr sessions.

Nābulusī, who lived in Damascus between 1050/1641 and 1143/1731, excelled in all of these genres, and features prominently in Nabhani's two anthologies. ${ }^{4}$ A "gnostic" and poet, he was skilled both in speculation on the "reality" (haqiqa) of Muhammad, and in the poetic description of his "attributes" $(a w s \underline{a} \bar{f})$. His work is representative of the polemical issues raised by the veneration of Muhammad, the vision of the world this veneration brought with it, and the practices centred on it. Nābulusìs engagement in these controversies provided Nabhānī with another reason to see him as an author who was still relevant. For Nabhānī, who was a civil servant of Ottoman justice during the Hamidian regime, promoting the cult of the Prophet also meant underlining one's support for the brand of Sunni orthodoxy that was favoured by the state, against its reformist and Wahhabi opponents. Writing in 1909, he invites "Muslims" to read Nābulusĩ in order to be forearmed against the "infatuated ones" (ba'd al-maftūnin) who spread the "innovations" of Ibn Taymiyya. ${ }^{5}$ About fifteen years later, and still during Nabhānī's lifetime, the cemetery of al-Baqi ${ }^{\mathrm{c}}$ in Medina was destroyed by the Wahhabites after the Saudi conquest of the

2 Nabhānī, Faụā̄il, 1231.

3 Nabhānī, Faḍāill, al-Majmū'a al-Nabhāniyya.

4 See the extracts from Nābulusī in Nabhānī, Faḍāil, 2: 685-702; 3: 106o-97 and 1214-32; 4: 1355-66; and Id. al-Majmū'a al-Nabhāniyya, 1: 12-15, 26, 25-31, 484-85; 3: 162; 4: 151, 248, 361-78, 393-96, 400, 406-409.

5 Nabhānī, Faḍāill, 3: 1221. 
Hijāz in 1924-25. Nābulusī lived and died before Ibn 'Abd al-Wahhāb had begun his predication, but even in his day voices were raised to remind the faithful that the cult of Muhammad's person was competing with the legalist conception of what the properly "Islamic" practice of Islam should be: that of a religion that has cut all ties with its "idolatrous" environment. The mawlid does not, in fact, celebrate the birth of Islam, but that of Muhammad, who was God's well-beloved even before his encounter with the angel Gabriel and, indeed, from before his birth. Some people rejected the doctrine according to which the "Muhammadan light" (nür muhammadī) was transmitted from Adam to Muhammad by an uninterrupted line of pure beings, objecting that the Prophet's parents were mere idolaters. This debate, which has been well described and studied by Joseph Dreher, also called into question Ibn 'Arabì's Fantastische Philosophie 6 and the ritual of the mawlid, which celebrates the Prophet as well as his Arab ancestors and his mother, Ämina. In one of his mawālèd, Nābulusī calls Muḥammad's mother "luminous beauty" (bahja

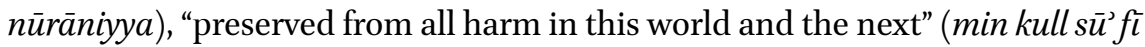
al-dārayn āmina.$^{7}$

In Nābulusì's time we can find a direct attack on the veneration of the Prophet in the Arabic-language sermons of the Anatolian preacher Ahmad al-Rūmī al-Aqhiṣārī (d. 1041/1631 or 1043/1634). ${ }^{8}$ Drawing on Ibn Taymiyya and Ibn al-Qayyim, Aqhișāin reminds his hearers that the ban on visiting tombs applies equally to the tomb of the Prophet. ${ }^{9}$ He compares the veneration of tombs to the "idolatry" of "the people of the Book",10 affirming that the rule (hukm) of Islam on the subject of mosques built over tombs is that they must be destroyed down to the ground (anyanhadim kulluhā hattā yusāwā bi-l-arḍ), ${ }^{11}$ and mentions that the Caliph 'Umar had the tree under which the Prophet received the pact of allegiance (bay'a) cut down when he noticed that people were venerating it. ${ }^{12}$

Aqhișārī was a Qadizadeli, and thus belonged to a current of opinion that Nābulusī would be confronting throughout his life. Iconoclastic attitudes such

6 Dreher, "Polémique", 296. Dreher takes up Balic's definition in Das unbekannte Bosnien, 223 .

7 Nābulusī, Haqīqa, 107. Nabhānī, Faḍāill, 3: 1063, reproduces the text of another mawlid in which Nābulusī recounts the legends of Āmina's pregnancy and Muhammad's birth. For more on this theme, see Holmes Katz, Birth, 35-39, 54, 61, 169, 172.

8 Michot, Against Smoking.

9 Aqhịạāīi, Majālis, 127 (majlis 17), 359 (majlis 57).

10 Aqhịisārī, Majālis, 127 (majlis 17).

11 Aqhișārī, Majālis, 129.

12 Aqḥiṣārī, Majālis, 128. 
as these, though rare at the time ${ }^{13}$ - despite occasionally being exploited by those in power - spring from problems that go beyond questions of what is permitted or forbidden. I will leave juridical polemics in the background and concentrate on the aesthetic and literary dimensions of the presence of the Prophet in Nābulusīs work. This approach allows one to look deep into the impacts and effects of the veneration of the Prophet, especially as regards the place of the imagination in human experience. For Nābulusī the texts, objects, and rituals relating to the cult of the Prophet constitute a "patrimony" that is artistic as well as religious, and the defence of this patrimony must reflect deeply on the nature of the "Muhammadan heritage" and the modes of its transmission and its appropriation, along with all the consequences these may imply for the conception of authority, and the relationship of Islam with the other "prophetic" religions, particularly Christianity.

\section{Seeing the Prophet in a Dream}

The best introduction to the study of the presence of the Prophet in Nābulusi's work may be through the theme of the dream-vision in which one encounters the Prophet. He writes of every aspect of such dream-visions, whether as experienced by ordinary believers or by accomplished mystics. He offers a general overview of the subject in his extensive dictionary on the interpretation of dreams (written in 1096/1685), which remained one of his most popular works and still enjoys a wide circulation today. ${ }^{14}$ Nābulusī is not laying claim to originality in this book. He analyses the hadith, "whoever sees me in a dream has really seen me" (man ra'ānī fì manāmihi fa-qad ra’āni ḥaqqan), "whoever sees me in a dream will see me when awake" (man ra'ānī fi l-manām fa-sa-yarāni yaqzatan), using a slightly abridged transcription of Ibn Hajar al-Haytamī's commentary. ${ }^{15}$ Nābulusī had already used an exact copy of this passage in a short treatise, still extant in manuscript form only, dated before 1089/1678.16 This treatise is a hilya, a description of the physical and moral characteristics of the Prophet, made with the devotional aim of helping the

\footnotetext{
13 Heyberger, "Entre Byzance et Rome", 534: According to Catholic missionaries, Muslims were more respectful of holy images than were Huguenots.

14 Lory, Le rêve, 127-129.

15 Ibn Ḥajar al-Haytamī, Ashraf al-wasāill, 596-599; compare Nābulusī, Ta țìr, 2: 213-214. On the ahädith and their variants, see Lory, Le rêve, 46; on their interpretation, ibid., 149162. For the English translation of the canonical version see Muslim, Sahīh, 6, 123-124 (k. al-ru'yā 10-11).

16 Nābulusī, Izälat al-khafä̀, 6a-8b. On the date, see Aladdin, 'Abd al-Ġanī, 1, 119 .
} 
reader to visualise him. Nābulusī says in his introduction: "I translate in the clearest terms the descriptions of the Prophet transmitted by tradition in order that the believer may familiarise himself with his qualities (awșâf $)$ and depict his appearance in imagination (yarsum shaklahu fi khayālihi), in the hope of seeing him in a dream ('asā yarāhu fi manāmihi)." This descriptive section is followed by a discussion on the "truthfulness" of dreams in which the Prophet appears. The framing of this is significant: since the hilya is a verbal portrait based on the hadith, that is to say on a description validated by eye-witnesses, it can serve as the basis for a vision identical with Muhammad's historical appearance, thus inscribing such dreams within a practice of preserving memory. But the passage that interests us here provides a corrective to this idea: in fact, it contains a critique of the opinions of a group of scholars that includes Ibn Sīin, the "father" of Arab dream-interpretation, according to whom the appearance of the Prophet in a dream is only authentic if he manifests the traditionally-attested qualities. The contrary opinion, adopted by a current that became the majority, was formulated as follows by the Andalusian scholar Abū Bakr b. al-'Arabī (d. 543/1148):

The vision of the Prophet that conforms to his description as we know it is an apprehension (idräk) of reality (haqiqa), whereas, if he is seen in another form, this is the apprehension of an image (mithāl). Since the earth [in which they are buried] does not corrupt prophets, the apprehension of the noble person (dhāt) of the Prophet is a reality, whereas the apprehension of his attributes is an image. [...] When the Prophet says: "whoever sees me in a dream has really seen me", this means that if that person saw him when awake he would find a perfect correspondence with what he had seen while dreaming. The waking vision is authentic and real (haqqan wa-haqiqatan), whereas the dreaming vision is authentic and representative (haqqan wa-tamthïlan). ${ }^{17}$

While the first outlook sets the truthful dream against the untruthful dream, according to the criterion of the dream's conformity with the description transmitted by tradition, the second distinguishes between the "reality" (in its proper sense) of the vision of the Prophet's person (his $d h \bar{a} t$ ), and the figurative representation of his qualities.

It is exaggeration and foolishness - continues Abū Bakr b. al-Arabī to say that we see our dreams with the eyes of our heads; according to

Nābulusī, Izālat al-khafā', 6b; Nābulusī, Ta'țīr, 2: 213. 
certain theologians, however, dreams are perceived by the eyes of the heart, and they are a kind of metaphor (innahu darb min al-majāz). ${ }^{18}$

This position implies that the mithāl is accorded the status of figurative representation of reality. Abū Bakr ibn al-'Arabī, who, during his travels in the Near East, had studied with al-Ghazālī, takes the same position on this point as the latter had; it is synthesised thus by Pierre Lory: "the vision of the Prophet cannot be that of his physical person, nor of his spirit or essence, but that of a representation in a symbolic mode of this spirit, and this representation is fully true."19

This distinction between the symbolic representation of Muhammad and his actual being lies behind Nābulusis's approach to the much-debated question of the waking vision of the Prophet. Nābulusī several times declares that he believes those of his contemporaries who say they have had such visions, ${ }^{20}$ but he never, as far as I know, laid claim to having had one himself. The intimate relationship with the Prophet of which he writes, in works destined for an audience of Sufis, is not described as a vision of his person, but as an existential experience. In his commentary on a prayer on the Prophet attributed to Ibn 'Arabī, he described "joining" (iltihâaq) with Muhammad as reaching his "incorruptible reality", which he identifies with the barzakh, "the isthmus". Initiates may enter into this latter, which is "the threshold between the servant and his lord", while they are still alive:

This barzakh, he says, is the haqiqa muhammadiyya: anyone who voluntarily dies to this world and to his carnal soul, and realises the station of Islam (maqām al-islām), enters into this barzakh which is his reality (haqiqa), that is, the reality from which he has been created, the light of Muhammad that comes from the light of God (alladhì min nūr Allāh), since earthly life has not changed it in any way (lam tughayyirhä al-hayāt al-duny $\bar{a}) .{ }^{21}$

In a similar way, at the beginning of a treatise addressed to his Suf "brothers", he says: "May God pray on Muhammad, thanks to whom, by the blessing of his

\footnotetext{
18 Nābulusī, Izālat al-khafä̀, 8a.

19 Lory, Le rêve, 15 o.

20 Nābulusī, Haqīqa, 378; Nābulusī, Wird, 106a-b; Nābulusī, Kashf, 3: 1162 (Nābulusī specifies here that sometimes the Muhammadan reality "is embodied in human shape": "tujassadu fi haykal basharı’”). See also Nabhānī, Fậ̣̄̇il, 3: 1066.

21 Nābulusī, Wird, 6o a-b. For more on this text, written in 1141/1729, see Gril "Jawāhir", 49; Aladdin, 'Abd al-íGanì, 1: 233.
} 
imitation (barakat mutāba'atihi), God opens a little window (kuwwa) in the heart to the presence of the invisible (hadrat al-ghayb)."22

Here we can observe that the debate on the nature of the Prophet's image, which concerns both prayer and dreams, corresponds to the distinction between the two styles in which he is figuratively represented in miniatures, as studied by Christiane Gruber: the dream that conforms to the "transmitted description" corresponds to memory images, illustrations of episodes in the Prophet's life that are notable by their "verism", while the image of the Prophet as a reflection of his metaphysical reality corresponds to his symbolic representation as a figure of light. ${ }^{23}$

The symbolic dream has the same function as the icon: like the icon, it is not the "illustration" of a memory, but a reflection of an actual presence. The analogy between dream and icon is the opening theme of a famous essay by Pavel Florensky, a Russian orthodox theologian and coeval of Nabhānī, and a passionate defender of the aesthetic of the icon and its conceptual universe at a time and place when these were being swept away by the Soviet regime. For Florensky, every icon, even one that is "poorly executed", can be "a window on eternity", because "it necessarily authenticates perception of the world beyond the senses through an always authentic spiritual experience". Thus the copy of the prototypical icon has the same "spiritual content" as the original, "though it may be in a veiled, dimmed, or dulled medium.". ${ }^{24}$ In the same way, the Prophet, like the sun, can be seen at the same moment by many people, and his image varies according to the clarity or cloudiness of the heart that reflects it. ${ }^{25}$ The Prophet, in other words, is the prototypical image of God that

22 Nābulusī, Risāla, 12a. This text is also transmitted under the title al-Rusūkh fi maqām al-shuyūkh; see Aladdin, 'Abd al-Ġanī, 1: 189 .

23 Gruber, "Between logos", 229. For more on the opposition between "memory" and "presence", see Bettetini, Contro le Immagini, 101-102, 116-30. The question was already being asked in debates within Egyptian Monachism; see Camplani, "Il dibatitto sulla visione", 154 .

24 Florensky, Iconostasis, 74. Later in the same passage, Florensky explains the relationship between the prototypical icon and its hand-made reproduction, as distinct from "mere servile mechanical reproduction", saying: "In a manuscript you write describing a country someone else has previously described in an earlier manuscript, you will see your own words and phrases in your very own handwriting; but the living basis of your manuscript is assuredly identical with that of the earlier one: the description of the country. Thus, the variations arising between successive copies of a prototypical icon indicate neither the illusory subjectivity of what is being depicted nor the arbitrariness of the icon-painting process but exactly the opposite: the living reality, which, remaining itself, nevertheless will appear with those variations that correspond to the spiritual life of the icon painter who seeks to comprehend that living reality".

Nābulusī, Izālat al-khafä̀, $7 \mathrm{~b}$. 
the dreamer copies within himself, and the "authenticity" of the copy does not depend on the exactitude of the reproduction.

In Nābulusìs work, the validation of symbolic dreams is connected to the defence of innovations in worship and a claim to spiritual authority conceived as a "Muhammadan inheritance" (wirātha muhammadiyya), accessible through a journey of individual transformation, without any need for the mediation of a formal hierarchy. These two levels are interdependent: it is as a "Muhammadan inheritor" that Nābulusī allows himself to take a stand in the great and divisive debates of his time. In his dream-journal, he makes a detailed note of a dream-vision he had one night in the month of Rajab 1088/1677, in which the Prophet told him to speak publicly. He relates how, in this dream of investiture, he was at once himself and the Prophet. ${ }^{26}$ The manuals of dream interpretation studied by Pierre Lory say that "for he who sees himself as the Prophet in a dream, this means that he will also pass through the trials that Muhammad faced during his life."27 In Nābulusì's case, these trials were the disapproval of his opponents, who resisted his "Muhammadan" explications of the sunna and the sharita: he completed his courageous treatise in defence of the $s a m \bar{a}^{c}$ barely a month after having received this dream. ${ }^{28}$

As Pierre Lory indicates, the typological approach to the analysis of dreams contains traces of Christian Old Testament exegesis. ${ }^{29}$ The typological method, which is also used in hagiography, offers a key to interpreting the individual's role in society. The "resemblance" between a saint and Muhammad, and between the former and other prophets, takes on political implications once it is recognised by the saint's contemporaries. A considerable number of the dreams recorded in Nābulusīs journal are not his own but those of people around him who claim to have dreamed of him as the Prophet. ${ }^{30}$

The tool Nābulusì uses to obtain public recognition is the written and spoken word. In the hagiography written about him at the beginning of the nineteenth century, his charisma relates to his power of persuasion, his ability to transform other people's "gaze" (nazar), to bring out emotions, especially in his

\footnotetext{
26 Ghazzī, Wird, 441-442.

27 Lory, Le rêve, $15^{2}$.

28 Compare Aladdin, 'Abd al-Ganī, 1, 108.

29 Lory, Le rêve, 159.

3o Ghazzī, Wird, 470-71, 472, 477-78.
} 
polemical writings that "fulfil the hearts of those who have the knowledge, and tighten the chests of the incredulous or oppressive ones." ${ }^{31}$

In spite of the effectiveness of Nābulusì's pamphlets defending controversial practices, or of the theoretical treatises in which he seeks to help readers understand Sufi metaphysics, it is in his poetry, through which he experiences spiritual "realities" and makes others experience them, that his way with words is most powerful. His hagiography shows us the role of the creative or poetic imagination in the "Muhammadan inheritance" to which Nābulusī lays claim, saying that he had entered the "land of the sesame seed" (ard al-simsima); the author draws his description of this immense and marvellous "land" from Ibn 'Arabī, transcribing a long passage from the Illuminations of Mecca that was made famous by Henry Corbin. ${ }^{32}$ This "land", that is identical with the "imaginal world" ('älam al-khayāl), is located in the barzakh. As we have seen, to reach this world is, for Nābulusī, to achieve union with the haqiqa muhammadiyya. Let us pause a moment to try to cast light on the relationship between language and imagination, before we examine the literary aspect of the veneration of the Prophet in Nābulusìs work.

The mediating function of this "isthmus" or "in-between world", which is the place where opposites meet, is shared by all the forces or faculties that enable the relationship between the earth and the heavens (such as angels) or between the intellect and the senses (such as the faculty for imagination); this also applies to relationships between two subjects, which are mediated by language. The definition of the imaginal world as "the world through which spirits are embodied, and bodies spiritualised",33 does indeed also apply to the act of communication. Ibn 'Arabì defines 'ibāra ("expression") as the transfer of the imaginal representation (khayāl) of the soul from the speaker to the listener, by means of words. ${ }^{34} \mathrm{He}$ underlines that the term tabir indicates both the expression through which the speaker gives a formal and materially supported consistency to an invisible meaning, and the interpretation through which the listener accomplishes the inverse process, translating the words into an inner image. This demonstrates that all language is metaphorical, requiring interpretation, and thus that the imagination has a "mighty rank" ( 'izam rutbat al-khayāl), because it controls (hākim) all knowledge. ${ }^{35}$

\footnotetext{
31 Ghazzì, Wird, 95.

32 Ghazzī, Wird, 515; see the translation of chapter 8 of the Futūhāt $(1,126-131)$ in Corbin, Corps spirituel, 164-72 (English translation, 135-43).

33 Corbin, Corps spirituel, 109 (English translation, 84).

34 Ibn 'Arabī, Futūhāat, 3, 453-54.

35 Ibn 'Arabī, Futūhāt, 3, 454.
} 
This passage from Ibn 'Arabī appears to be in dialogue with the Greco-Arab traditions of logic and philosophy. His definition of the term ta'bir corresponds perfectly to the Greek hermeneia, which forms the title of Aristotle's Peri hermeneias; this can be translated as "On Interpretation", or "On Expression", as in the ninth century Arabic translation ( $f i l-i b \bar{a} r a) .{ }^{36}$ This definition of $t a{ }^{\prime} b \bar{c}$ also corresponds to that of poetic discourse in Arabic commentaries on Aristotle's Poetics and Rhetoric, where this discourse is called takhyull, and defined as: "the creation of mental images (khayālāt) by the poet for the 'imagination' (alquwwa al-mutakhayyila) of the listener". ${ }^{37}$ In the canon of Aristotle's works in late antiquity and then in the Islamic world, the Poetics and Rhetoric were placed at the end of the Organon, the treatises on logic. For the faläsifa, poetic discourse is distinguished from logical propositions that are true, precisely because it engages the imaginative faculty, and thus contains an element of illusion. By extending the definition of poetic discourse to include all acts of communication, Ibn 'Arabī sets himself apart from the philosophical hierarchisation of discourse, but his attitude is not incompatible with a philosophical approach to rhetoric. ${ }^{38}$ What he has to say about the power of the imagination recalls Averroes' words at the beginning of his commentary on the Rhetoric: like the other parts of logic, the science of rhetoric does not have a specific aim; it is a method, or instrument, that can be used in all the other sciences and is thus in some way associated with them. ${ }^{39}$ According to Averroes, rhetoric and dialectics are to be distinguished from other aspects of logic, "since man does not use these two arts to converse with himself (baynahu wa-bayna nafsihi), as is the case for the art of demonstration, but uses them only with other people (ma'a l-ghayr)".40 This definition also applies to poetry, not as shir,

36 Compare the explanation of this double meaning of the Greek hermeneia by Grondin, Introduction, 20-21: 'In 'expression' spirit, as it were, makes what is contained within knowable from without, whereas 'interpretation' tries to penetrate an uttered expression to see the spirit contained within it."

37 Heinrichs, "Introduction", 5 .

38 See Lizzini, "Le langage de Dieu", 23: "Le modèle dualiste qui opposerait un langage non rhétorique et porteur de vérité à la langue des images et de la poésie semble incompatible avec la philosophie élaborée dans l'islam, qui doit pouvoir reconnaitre la vérité (aussi) dans le langage rhétorique et poétique" ("The dualist model that opposes a non-rhetorical, truthful language and the language of images and poetry seems to be incompatible with the philosophy elaborated in Islam, which must be able (also) to recognise the truth in rhetorical and poetic language").

39 Averroès, Commentaire, 2, 1-2, par. 1.1.1. Thanks are due to Francesca Gorgoni for having brought this passage to my attention.

Averroes, Commentaire, 2, 1-2, par. 1.1.1. 
which refers to an "intimate" discourse, ${ }^{41}$ but as nazm, a versified discourse. Among the "strange and marvellous" things that Ibn 'Arabì saw in the "land of the sesame seed" was a "vessel of stone" navigating a sea of sand. Claude Addas has pointed out that this apparently surrealist description is in fact a riddle, alluding to the classical ode ( qașida). Ibn 'Arabī brings about a double meaning by using technical terms from Arabic prosody in their concrete sense (for example, $b a h \mathfrak{r}$, which means both "sea" and "metre"). ${ }^{42}$ This fantastical metaphor is an example of takhyil, in the specific sense that this term has had in Arabic criticism since the time of 'Abd al-Qāhir al-Jurjānī (d. 471/1078 or 474/1081). Beatrice Gruendler defines it thus: "tropes with arresting fantastic features that purported to be true. They all shared the blurring of the borderline between reality and image and the interpenetration of these two planes with an illogical or fantastic effect, construed with logical tricks and figures of speech". ${ }^{43}$ This manner characterises the "new style" (badī) invented by poets from the beginning of the 'Abbāsid period; through the same distinctive evolution, badi moves to signify "rhetorical artifices". The imaginal world, in which, Ibn 'Arabī says, "a multitude of things exist which are rationally impossible", ${ }_{4}$ is certainly a fitting locus for this "fantastic aesthetics". Ibn 'Arabī's approach is nevertheless quite distinct from that of a literary critic, such as Jurjānī, for whom this style perfectly demonstrates the maxim khayr al-shi'r akdhabuhu, "the best poetry is that which lies' the most."45 In fact, for mystical poetry the takhyil tends rather to prove that it is possible to bring the real and the fictional together, and that this happens before our very eyes if we can perceive the invisible meanings of things by looking at them "subtly".

In the chapter in which Ibn 'Arabì defines the ta'bìr, he also explains that God reveals Himself to us through His Names and through similes (darb al-amthäl), and through "the world of imagination", in order to establish a relationship with us: some people adore Him and never go beyond the form; other, less fortunate, people aspire to make the form into an abstraction, and the ones who are perfect unite the faith of the first with the intellect ('aql) of the latter. ${ }^{46}$ Ibn 'Arabi’s "literalism" sets him apart not only from philosophers but also from rationalist theologians. ${ }^{47}$ In spite of this, he does not reject the analogy between rhetorical discourse and prophetic discourse,

\footnotetext{
41 Compare Nābulusī, Kashf, 1, 71: al-shi'r hadìth al-nafs fìmā tash'ur bihi min al-ma'ānī.

42 Addas, "Le vaisseau de pierre".

43 Gruendler, "Fantastic Aesthetics", 215; see also Heinrichs, "Introduction", 11.

44 Corbin, Corps spirituel, 166 (137 in English translation).

45 Heinrichs, "Introduction", 12.

46 Ibn 'Arabī, Futūhāt, 3, 450-451.

47 Chodkiewicz, Océan.
} 
which is part of the philosophical reading of prophecy - but he does emphasise the loving intention behind the exteriorisation of divine discourse, which means that its ends can be achieved even through the "imaginative" faith of non-intellectual believers. Ibn 'Arabī's attitude is incompatible with al-Fārābī's political interpretation of prophecy, according to which the Prophet's rhetoric, like Plato's myth, serves to govern the masses who are incapable of knowing the truth ... but it does have things in common with the more nuanced positions of Avicenna and Averroes. ${ }^{48}$

\section{3}

\section{Poetry and haquíqa muhammadiyya}

As we shall shortly see, these knotty questions are at the heart of Nābulusìs reflections on poetry and haqiqa muhammadiyya. Nābulusī puts his fantastical poetry in the service of veneration of the Prophet in his account of a journey to Palestine, al-Hadra al-unsiyya fi l-rihla al-qudsiyya, "the presence of intimacy in the journey to the Holy Land". As Gracia López Anguita has observed, this title refers to the holiness of Jerusalem, and of Palestine in its entirety, as an "intimate" pendant to the holy places of the Hijāz; these holy spaces are both analogues - because the stages of the Palestinian itinerary are "comparable" to those of the Hijāz - and complements: Nābulusī says, speaking of the al-Aqșā mosque, "God has looked at this mosque with the eye of Beauty, and at Mecca with the eye of Majesty."49 Right from the beginning of his book, Nābulusī affirms and upholds the legitimacy of this pilgrimage, in response to the attacks of Ibn Taymiyya and other scholars on the religious merits of Jerusalem and its prophetic relics. When describing its culmination, the visit to the Dome of the Rock (Qubbat al-sakhra), he examines the legends and polemics relating to the Prophet's footprint on the rock. Nābulusī first refutes sceptics in prose, presenting several arguments in support of the credibility of the account, which holds that when the Prophet was ascending from the earth the rock from which he rose melted with tenderness for him and sorrow at the parting. But the most important parts of Nābulusī's argument are expressed through poetry:

48 Ibn 'Arabī explicitly rejects al-Fārābī's position, without naming him, though he does mention the title of one of his books, in Futūhāt, 3, 178. For more on this passage, see Rosenthal, "Ibn 'Arabī", 19; Brague, La loi, 299-30o. On Avicenna's theory of the imagination, and his affinities with Ghazālī and Ibn 'Arabī: Michot, Destinée, 212-217. On the objections of Averroes to Plato's political philosophy: Leaman, An Introduction, 184-85. On Ibn 'Arabī's encounter with Averroes: Bashier, Ibn al-Arabìs Barzakh, 59-74.

López Anguita, "La rị̣la", notes 38 and 53. 
Oh God's venerated boulder, the heart of love's slave does not stray from its passion for thee.

Thou art a spirit emerging within my thoughts, a light embodied outwith mine eyes $[\ldots]$

How tender, this rock, for one who knows its virtue, but for he who does not it is so hard!

Oh subtle secret that appeared from the sky's zenith, like the sun shining from the horizon!

Although eyes see it coarsely because in human language it has assumed the name of "rock". 50

The footprint in the rock says it will function only if the pilgrim detaches himself from appearances, and from the obvious meanings of words, and understands that it is a veil, or a threshold, between the visible and the invisible. However, we must specify that Nābulusī does not see the "gnostic's" perception as qualitatively different from that of the ordinary believer: for example, in a qașida composed in Medina on the subject of the Prophet's tomb, he lists the many inspirations that the mystic draws from it and also the healing that it brings to the ordinary devout people who are clinging to the fence. ${ }^{51}$

The transformative power of Nābulusî's gaze surpassed that of alchemists, according to his biographer, who recounts that a Maghribi who was passing through Damascus offered to teach him Art (al-șan'a), but in reply Nābulusī asked him to look out the window: there the visitor saw Mount Qasiyun turn to gold before his very eyes. ${ }^{52}$ In the journal he kept during his travels to Egypt, Nābulusī transcribes a fantastical comparison whose subtlety had struck him (takhayyul latîf), and then imitates it, with the addition of an alchemical theme:

According to this model we have imagined the following unparalleled concept:

When the sun sets and the waves are moving

brighter than the stars does the sea glow,

just as silver melted by the flame's heat

50 Nābulusī, Ḥadra, 121: yā șakhrata llāhi l-mu'azzamata llatī - qalbu al-mutayyami 'an hawāhā mā fatī| rūhun tașawwara fì bawāțini khāțirī - nūrun tajassada fì zawāhiri muqlatī / [...] hiya șakhratun lānat li-ārifi faḍlihāa-wa-qasat 'alā l-juhhāli ablagha qaswatī / sirrun lațīfun lāha min awji l-'ulā - ka-l-shamsi fì l-äfāqi dhāti ashi"atī / fa-hiya l-kathīfatu fì l-'uyūni li-annahā - aḍhat tusammā fì l-warā bi-l-ṣakhratī.

51 Nābulusì, Haqĩqa, 334.

52 Ghazzī, Wird, 5 o9. 
the elixir flows over it

and the alchemic ingots turn into pure gold. ${ }^{53}$

The institutionalisation of the mawlid propelled the madị nabawi to greater heights, and perhaps stimulated new reflections on the relationship between "technique" and "inspiration" in poetry. The growth of the genre is demonstrated by the fact that Būșinìs Burda (mantel ode) became a set text for those learning the art of rhetoric, and the fourteenth century saw the invention of the badiciyya sub-genre, consisting of imitations of the Burda in which each verse exemplifies at least one rhetorical artifice $(b a d \bar{\imath}) .{ }^{54}$ When he was twenty-five, Nābulusī composed a badīiyya, which marked his entry into literary society in Damascus. ${ }^{55}$ Nābulusī followed this poem with an extensive commentary, which is consultable today thanks to Pierre Cachia's work: he has extracted 180 detailed definitions of figures of style from it. This text gives us some idea of the level of elaboration that the art and science of badi had reached by Nābulusî's time. Cachia calls this book "a full exposition of the science [of the bad $\bar{\imath}]$ and of the aesthetic perceptions attending it at a significant juncture in cultural history", 56 that is to say, some time before the dawn of a new literary period which would (among other things) rid itself of the badic.

Yet Nābulusì's most important madāih are closer to love poetry (ghazal) than to the neo-classical qașida in the style of Būșīìi. These poems are collected in his dīwān entitled Nafhat al-qabülfimidhatal-rasūl ("Breath of the Southern Wind in praise of the Messenger"); there are 29 of them - one for each letter of the alphabet - and each poem comprises fifty verses. Here Nābulusì's style has similarities to that of Ibn al-Fārid (d. 632/1235), whom he considered more eloquent than Būṣīīi despite the latter's excellence in the art ( fann) of describing the virtues of Muhammad, Nābulusī believed that Ibn al-Fāriḍ was better at expressing how very indescribable these virtues are. ${ }^{57}$ In the preface of this dìwān, Nābulusī underlines the fact that here he does not repeat any of the praises of the Prophet that he had previously composed, instead relying on

53 Nābulusī, Haqūqa, 218: wa-takhayyalnā nahnnu min hädhà al-qabīl hādhā l-mánā lladhī laysa lahu mathïl: li-l-bahri waqta ghurūbi l-shamsi wa-d̦̣arabat - amwājuhu rawnaqun yazhū 'alā l-shuhubi / ka-fiḍ̂tin tahtahā l-nīrānu mūqadatun - hattā ghalat ba'da mā dhābat 'alā l-lahabi / fa-darra min fawqihā l-iksīru fa-nqalabat - sabāìku l-kīmiyā min khāliși l-dhahabi.

54 See Stetkevych, Mantle Odes, 70; Kilpatrick, "From Literatur to Adab", 214.

55 Aladdin, 'Abd al-Ġanī, 1, 156 (n. 150); see also ibid., 141, (n. 127), 152 (n. 145).

56 Cachia, The Arch Rhetorician, 2.

57 Nabhānī, Faḍ̂àil, 1071; Nābulusī, Kashf, 1, 116. 
his talent for improvisation (ámaltu qarịhatī fi nazmihà irtijālan). ${ }^{58}$ The main themes of these poems are the declaration of passionate love ( $i s h q$ ) for the Prophet, ardent desire (shawq) for the ziyāra in Medina, and the invocation of help against his enemies. The lyrical "I" of love's slave (mutayyam), hated and misunderstood by his peers, is identified with the Prophet at the time when his people rejected him. The identification of the poet/lover's censor with the Suf's adversary is one typical motif of the mystical ghazal. ${ }^{59}$ In the framework of the madih , this theme takes on a particular polemical power, putting the censor in the same category as Muhammad's Qurayshī adversaries. In the dīwān's preface, Nābulusī says that the motive (bāith) of its composition is his gratitude for the "healing" of a sickness. ${ }^{60}$ The fact that this is a conventional theme does not mean he was not sincere in advancing it. The affirmation in this preface of the unmeasurable distance between poets' praises of the Prophet and the inimitable praises for him found in the Quràn corresponds to the feeling of yearning brought forth in the poems by the absence of the Prophet. What's more, the Prophet's reality surpasses all beauty and the art of language cannot express it; in fact, the eloquence and clarity (balägha and fașäha a of language itself were created by his light. ${ }^{61}$ These statements represent a sort of profession of tanzih , of the un-bridgeable distance that separates the suffering poet from Muhammad's original light, and his poems from the words of the Qur'ān. Like the "opaque" dream, the poetic description of Muhammad tells us more about the value ( $q a d r$ ) of the person praising than it does about the one being praised. ${ }^{62}$

In his preface to his Dīwān al-haqā’iq, a retrospective essay looking back over his entire poetic production, Nābulusī also informs us about the place of the madị in his poetry. Here he enumerates the four poetic genres that he cultivated, comparing them to the four "gates" of Paradise, and to the four "corners" (arkān) of the Kaba. ${ }^{63}$ These genres are, in order, mystical poetry, the madih nabawi (represented by the Naf̣at al-qabül), the praises of contemporaries, and erotic poetry (ghazal). Although the last three of these genres are distinct in function and object, especially the madị nabawī, because it is addressed to those who follow the spiritual path, for Nābulusī the essential distinction is not

\footnotetext{
58 Nābulusī, Naf̣̣at, 7 .

59 See, for example, Nicholson, Studies, 139 (on the subject of Ibn al-Fāriḍ). For an example of the identification with the rejected Prophet, drawn from Ottoman mystics of Nābulusīs day, see Dreher, "Polémique", 298.

6o Nābulusī, Naf̣̣at, 7 .

61 Nābulusī, Naf̣̣at, 5-6.

62 Nābulusī, Naf̣at, 6.

63 Nābulusī, Dèwān al-ḥaqā̉iq, 1, 15-17.
} 
between sacred and profane poetry, but between mystical poetry, expressed in the "language of union" (lisān al-jam ), and the three other genres, all expressed in the "language of separation" (lisān al-farq).

Thus the madih nabawi belongs in the same group as the "profane" madīh and ghazal: all three are indirect expressions of reality because of their separation and distance from God. A single internal criterion is therefore more important than distinctions based on genre: the mystical poem is not necessarily distinguished from other poems by its formal qualities, but by the state of the poet while writing it. Nābulusī clarifies this point in two further texts: synthesising it in an autobiographical letter written in 1099/1687 to the Egyptian Sufi master Zayn al-'̄̄bidīn al-Bakrī al-Ṣiddīqī, in which he speaks of his "realisation of the station of inheritance" (tahqiq maqām al-wirātha) at the end of his retreat, ${ }^{64}$ and discussing it at length in his commentary on Ibn al-Fāriḍ's Dīwān, a commentary that covers more than 2000 pages in its unabridged version, which was only published in $2017 .^{65} \mathrm{~A}$ mature work completed in $1123 / 1711$, this commentary is also somewhat autobiographical: between the verses by Ibn al-Fāriḍ, Nābulusī paints the portrait of a theologian-poet exactly resembling himself. ${ }^{66}$

In these texts, unlike in the Nafhat al-qabül, the emphasis is not on distance, but on the resemblance between the Prophet and his heir. For his "heir", Muhammad is not just an object of devotion. He is also the model of the transformative experience through which a compiler-epigon becomes an "author" himself. The many passages on "Muḥammadan inheritance" in Nābulusī's work illustrate his conception of the continuity of prophecy. He emphasises the everrenewed descent of the divine word onto the heart of the saint who becomes capable of translating it into human language. ${ }^{67}$ The "heir", as an author who speaks in the first person, and whose words flow directly from his heart, bears witness to the relevance of prophecy. He is not imitating a model from the past, but has become a new "locus of manifestation" of "Muhammadan light".68

The "internal" similarity with the Prophet is the ultimate source of "authority". In his commentary on Ibn al-Fāriḍ, Nābulusī often insists that the "psychic 'I" (nafsānì) of the poet has become a rabbāni "I"; the adjective is derived from the word $r a b b$, meaning lord or master. In the Qur'ann, this term relates to teaching and to study ( $\mathrm{Q}$ 3:79), and it is also related to the verb rabba (to make [people] grow, to raise), from which we get the verbal noun tarbiya (education).

\footnotetext{
64 Ghazzī, Wird, 399-408.

65 Nābulusī, Kashf.

66 See the fine analysis by Homerin, "On the Battleground". Most of the extracts from Nābulusī in Nabhānī's Faḍāil come from this text.

67 Nābulusī, Hāamil, §§ 55-58; Gril, "Jawāhir".

68 Nābulusī, Natīja, question 1. See also Dīwān al-ḥaqā’iq, 2, 34.
} 
These meanings are semantically close to the Latin terms auctor and auctoritas (derived from augeo). As Hannah Arendt has shown, the function of auctoritas in Latin culture is precisely that of constantly "augmenting" the tradition established by the founders; it is incompatible with the violence that is the prerogative of power (potestas). ${ }^{69}$ For Nābulusī, religion springs from this domain of authority (auctoritas), rather than from power, and it must be imposed by the word, without recourse to force or constraints. ${ }^{70}$

The "heir" also resembles the Prophet outwardly, in his way of speaking. The Prophet and the "heir" both address their "people" (qawm) in the people's own language, translating divine speech ( kalām) into a figurative language communicating through that which is "other" than God. Nābulusī calls this language lisān al-ghayr and lisān al-siwā, and also the "language of separation" (lisān al-farq), distinguishing it from the "language of union" (lisān al-jam). Thus the first three terms refer to the consciousness of the separation between subject and object, between God and the world. ${ }^{11}$ Using an expression that recalls the philosophical interpretation of prophecy, Nābulusī says that prophets guide people by "wrapping the things [of this world] in symbols from the imagination" (labisū tamāthïla l-khayāl 'alā al-siwā). ${ }^{72}$ This figurative language is not "poetry", but, because of its formal aspects, it is associated (ishtaraka) with poetry, and therefore its true nature risks being misunderstood. ${ }^{73}$ In the same way that the Prophet was not a poet, the poetry of his "heirs" is not poetry, but a form of inspired discourse. ${ }^{74}$

69 Arendt, "What is authority", 120-22.

70 Pagani, "Défendre", 322.

71 Nābulusī, Dīwān al-haqāàiq, 1, 10-11; compare Ghazzī, Wird, 408. This distinction corresponds to that between the Qurān and the Furqān. Elsewhere (Kashf, 2, 744), Nābulusī says that the former is God's "interior discourse" (al-kalām al-nafsī), which does not belong to the genre of letters and sounds. The Furqān, on the other hand, is the descent of this discourse "through our letters, our words, our meanings". Among human beings there is also an interior language (nutq) ("the discourse and the meanings that we conceive in our souls through imaginative power") and a proffered language (al-nuțq al-lafži al-lisāni bi-al-mädda al-hawā'iyya). Compare the Stoic's distinction between logos endiathetos and logos prophorikos: Grondin, Introduction, 21. For more on this distinction in the ușūl alfiqh, see Weiss, Search, 68: "The Qurān is the internal speech (al-kalām al-nafsī) of God embodied in a phonic speech (al-kalām al-lisānī) which is of God's own making. [...] In the case of the sunna, the internal speech of God comes to be embodied in a phonic speech or in acts and endorsements that are of the Prophet's making".

72 Ghazzī, Wird, 399 .

73 Ghazzī, Wird, 407-408; Nābulusī, Dīwān al-ḥaqāंiq, 1, 13.

74 Ghazzī, Wird, 407-408; Nābulusī, Dīwān al-haqā̄iq, 1, 13; 2, 134 (wa mā anā shā ir wa-jamī nazmī baìd 'an madā shi'r al-mughannī); Nābulusī, Kashf, 1, 71, 132, 136-137. See also Homerin, "On the Battleground", 408; Addas, "Le vaisseau". 
Nābulusī applies this idea throughout his commentary on Ibn al-Fāriḍ: it is because Ibn al-Fāriḍ is a rabbānī poet that the haqīqa muhammadiyya speaks in the first person in his mystical poetry, or speaks "with his tongue" in his seemingly profane ghazal. ${ }^{75}$ In one remarkable passage, he describes the spiritual and poetic itinerary of Ibn al-Fāriḍ as a circular path: in the first phase, when the poet, through his perspicacity (bașira), discovers that the haqiqa muhammadiyya is the source of light, his tongue is untied (yanțaliqu lisānuhu) "and he composes figurative poetry (al-shi'r al-badī) according to his mastery of the poetic arts and literary sciences ('alä hasab mā 'indahu min ma'rifat al-șinā'a al-shi'riyya wa-l-ulüm al-adabiyya) [...], even if his discourse should be called a divine science rather than poetry". Then, when he passes into the state of annihilation $($ fan $\bar{a})$, his discourse separates itself from him (yanqațiu minhu al-kalām) and he openly proclaims the union (ittihăd) with God, believing himself to have passed the stage of the haqiqa muhammadiyya. But once he becomes settled in this station, he discovers that it does, in fact, belong to the haqiqa muhammadiyya, to the facet of it that is turned towards absolute unity, called haqīqa ạ̣madiyya by Nābulusī. At this point, and henceforth conscious that love for Muhammad and love for the true being (al-wujüd al-haqq) are one and the same, speech returns to him (yarjíu kalämuhu), and he begins once again to compose erotic poetry and celebrate the beauty of the apprehensible world, as he had at the beginning, except that now the person speaking is the only true speaker. ${ }^{76}$ This means that when the poet expresses his passion for the beautiful faces of boys or girls, even if this passion resembles that of a lover put to the test by "the love of images" ( ishq al-șuwar), the source and goal of his words is always the haqiqa muhammadiyya. ${ }^{77}$

Essentially, understanding the nature of the haqiqa muhammadiyya means grasping the continuity or co-existence of "subtlety" and "density", of the spirit and the body. This means that "reality" can be perceived by the five senses, as it can be perceived by spiritual intuition. ${ }^{78}$ In fact, Muhammad is the principle within which the spirit and the light, the two ways of exteriorising the invisible, join together. ${ }^{79}$ Nābulusī sometimes describes "Muhammadan light" as the "primal matter" (mādda hayūlāniyya) ${ }^{80}$ from which God, as demiurge

75 Nabhānī, Faḍàil, 1075-1076; 108o-82.

76 Nabhānī, Faḍāill, 1092-1094; Nābulusī, Kashf, 2, 833-834 (Ibn al-Fāriḍ, Tāìyya, verse 334).

77 Nabhānī, Faḍ̂ảil, 1094-97; Nābulusī, Kashf, 2, 835-36 (Ibn al-Fāriḍ, Tāìyya, verse 335).

78 Homerin, "On the Battleground", $385-86$. Nābulusī also comments on the verses translated by Homerin, in Wird, 13a-b.

79 Nābulusī, Kashf, 2: 831-832; Nabhānī, Faḍā̃il, 1091-92 (Ibn al-Fārid, Tã̉iyya, verse 333).

8o Nābulusī, Kashf, 3, 1162 . 
(șāni $)$, fashioned the world; 81 the clay from which Adam's body was made also comes from the flow (fayd) of this luminous material. ${ }^{82}$ Importantly, the body's "luminous" origin means that the original legal assessment of all things is "indifference" (al-așl fi l-ashya à al-ibāha), while any interdiction is secondary or accidental. ${ }^{83}$ This principle is the basis for the defence of listening to music, and of the "gaze", and also fits in with the maläma, "avoiding distinguishing oneself from the common believers", and refraining from avoiding (for fear of scandal, for example) the company of "people who are lost and corrupt" (ahl al-dalāl wa-al-fasād). ${ }^{84}$

The positive nature of the body also means that the entire human being, spirit, soul and body, is made in God's image, and therefore sacred, even if the individual is not a saint. Of course, this applies to Muhammad, the archetype, ${ }^{85}$ but in fact it applies to every human being, which implies that one must adopt every recourse available in law in order to avoid bloodshed. Ibn 'Arabī affirms this in the chapter on Jonas in the book "The Bezels of Wisdom". Nābulusì's commentary on this passage underlines the fact that the lieutenancy of God generally belongs to all human beings (khilāfa 'âmma), and not only to those who exert inner spiritual authority or external worldly power. ${ }^{86}$

It could be said that in some ways artists exercise this "lieutenancy" in the external domain, because they partake of God's "creativity". Ibn al-Fārid himself suggests this in the two groups of verses that follow - the first of these concerns Harīin's Maqāmāt, the summit of the prose badī:

My coining parables for thee time after time concerning my state is a favour from me to thee.

81 Nābulusī, Kashf, 2, 832; Nabhānī, Faụā̉il, 1091-92.

82 Nabhānī, Faḍāill, 1088-89; Nābulusī, Kashf, 2, 812 (Ibn al-Fārị̣, Tā̉iyya, verse 313). This idea had been formulated as early as the ninth century by Sahl Tustarī: see Holmes Katz, Birth, 14.

83 Nabhānī, Faḍāill, 1088-89; Nābulusī, Kashf, 2, 812.

84 Nābulusī, Kashf, 2, 563 (Ibn al-Fārị̣, Tãìyya, verse 8o).

85 Nābulusī, Jawāhir, 3og: Ibn 'Arabī says that Muhammad is "triple" (muthallath al-nash') because his constitution is based on three principles, wa-huwa al-haykal al-shariff

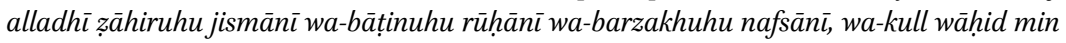
al-thalätha allatī fihi 'ayn al-äkhar min wajh wa-ghayruhu min wajh.

86 Nābulusī, Jawāhir, 2: 19o. "Anthropomorphite" monks of the fourth and fifth centuries also believed that all men carry the imprint of God's image within their physical forms: see Camplani, "Il dibattito sulla visione", 161. Like Ibn 'Arabī and Nābulusī, they drew important legal and ethical conclusions from this belief: Del Cogliano, "Situating Serapion's Sorrow", 404 . 
Consider the Maqāmāt of the Sarūjite and draw a lesson from his variety (of disguise) [...].

And thou wilt perceive that the soul in whatever form and shape she appears, inwardly masks herself in sensation;

And if his (Harīrîs) work is fiction, yet the Truth makes of it a parable. ${ }^{87}$

The second group of verses concerns shadow-theatre:

And beware of turning thy back on every tinselled form or unreal and fantastic case;

For in the sleep of illusion the apparition of the shadow-phantom brings thee to that which is shown through the thin (semi-transparent) curtains. ${ }^{88}$

On the subject of these latter verses Nâbulusì says that all these things are "examples and parables forged for you, by the creative action that God realises through human hands" ('ibar wa-amthāl madrūba laka bi-khalq Allāh ta'ālā 'ala aydī al-nās). ${ }^{89} \mathrm{Ibn}$ 'Arabì remarks that human creations spring from the divine Names: the Name $a$-Bad ${ }^{\prime}$ (the Originator) corresponds to the man who "has invented [something] within himself, then made it appear"; 90 from the Name al-Bäri (the Creator) "derives the inspiration for painters in bringing beauty and proper harmony to their pictures".91

In his commentary on Ibn al-Fāriḍ, Nābulusī wants to create an original work: in fact, he proposes to fuse the two distinct readings that men of letters

87 Ibn al-Fāriḍ, Tã̉yya, vv. 655-58 (trans. Nicholson, Studies, 200), in Nābulusī, Kashf, 3, 1172. Wa-ḍarbì laka l-amthāla minnīya minnatun - 'alayka bi-sha’nì marratan ba'da marratī / ta'ammal maqāmāti l-Sarūjiyyyi wa-tabir - bi-talwīnihi [...] / wa-tadrī ltibāsa l-nafsi bi-l-ḥissi bāținan - bi-maz̧harihà fì kulli shaklin wa-șūratī / Wa-fì qawlihī in māna fa-l-haqqu ḍaribun - bihì mathalan [...]. Nābulusī mentions elsewhere that the Egyptian scholar Ibn Ḥajar al-Haytamī was asked for his legal opinion on whether a person who says that Harīīìs Maqāmāt are lies should be declared an infidel because in so doing he would ridicule knowledge (li-istihzä̉ihi bi-l-'ilm): Nābulusī, al-'Uqūd, 24.

88 Ibn al-Fārị̣, Tā̉iyya, vv. 679-8o (trans. Nicholson, Studies, 202), in Nābulusī, Kashf, 3, 1187f.: wa-iyyāka wa-l-irāộ 'an kulli șūratin - mumawwahatin aw hālatin mustahīlati I fa-țayfu khayāli l-zilli yuhdī ilayka fì - karā al-lahwi mā 'anhu al-satāiru shaffati. The symbolic interpretation of the shadow theatre has been further taken up by one of Nābulusì's disciples: see Aladdin, "Abd al-Ghanī al-Nābulusī", 43f., referring to Baytamānī, Kashf al-asrār fol. 281a. On this manuscript, see Māliḥ, Fihris, 2, 503f.

89 Nābulusī, Kashf, 3, 1188.

$90 \quad$ Abdel-Hadi, "Unexplored Concepts", 73, translation of Chapter $55^{8}$ of the Futūhăt.

91 Ibn 'Arabī, Futūhāt, 2, 424, translated in Hirtenstein, The Unlimited Mercifier, 7. On this passage from the Futūhāt see further Puerta Vílchez, Aesthetics, 814. 
and "Akbarians" have of Ibn al-Fāriḍ's poetry, while avoiding the excessively technical elements of either group's approach. ${ }^{92}$ Nābulusì's accessible and discursive style is closer to the $a d a b$ than to the irfān..$^{93}$ As Denis Gril has said, Nābulusî has a place of his own in the tradition of interpreters of Ibn 'Arabī, who are mostly of Persian culture and have a more philosophical style. Not only are Nābulusī's explanations addressed to a non-specialised audience, but his commentaries include many personal touches that allow the reader to glimpse his originality and the things he holds dearest. ${ }^{94}$

Two of Denis Gril's comments are particularly interesting for our purposes. The first has to do with terminology: alongside haqiqa muhammadiyya, a technical term from Ibn 'Arabī, Nābulusī also often uses the older term nūr muhammadì, an indicator of his preference for a language that is closer to the hadith. The second of Gril's insights is stylistic: in order to explain the expression "word of God", Nābulusî compares the utterance of the divine verb with the human act of language, thus emphasising the physical dimension of this process.

It could be said that interest in the "form" of revelation, the letter, body of the word, is one aspect of Ibn 'Arabỉ's teaching to which Nābulusī pays more attention than do Persian commentators. In doing so, he aligns himself not only with the "Arabic" poetry of Ibn al-Fārid, but with the "realism" of traditional exegesis, which is linked to a belief in the representability of God in human form, and to the identification of the Qurann with the word of God. This proximity goes beyond the literary: in Damascus, Nābulusĩ frequented the Hanbali circles of the Saalihịyya quarter, among which a pietist tradition that was open to Ibn 'Arabï's mysticism had been cultivated since the beginning of the Ottoman period. ${ }^{95}$ This is not surprising: the Hanbali refusal of the rationalist allegorisation of the figurative expressions in the Qurān and the hadith is not incompatible with a symbolic and mystical interpretation, and in fact this outlook encouraged the early rapprochement between religion and love poetry in devout traditionalist circles. ${ }^{96}$ This form of devotion, common

92 Homerin, "On the Battleground", 359-6o.

93 See, as a contrast, Scattolin, "The Key Concepts", 78-79.

94 Gril, "Jawāhir".

95 El-Rouayheb, Intellectual History, 262-264, 285-294; Voll, "Abd al-Ghanī al-Nābulusī", 195-209.

96 Vadet, L'esprit courtois, 379-430. More recently, Williams, in "A Body Unlike Bodies", 44, underlined that classical Sunnī traditionalism is not iconoclastic, but exists in continuity with the "transcendent anthropomorphism" of the Bible, the Near East, and the Qurān. In addition, Jokisch, Islamic Imperial Law, 5०3-508, compares the controversies between Sunnīs and their Jahmite and Mu'tazilite adversaries with those between Byzantine iconophiles and iconoclasts during the same period. 
to Sufis and medieval Hanbalis, has been accused of anthropomorphism and resemblances with Christianity. ${ }^{97}$ Since I have alluded several times to the conceptual affinities between the cult of icons and the veneration of the Prophet, I will now expand on this point. The defenders of icons were obliged to prove to their adversaries that the image of Christ could be venerated in a material support - the wood of the icons or the bodies of living saints - without this support being made divine in itself. The first formulation in Arabic of these arguments can be found in the treatise on the subject by the bishop of Harrān, Theodor Abū Qurra (c. 755-830), who was active in the movement to translate Greek philosophy into Arabic. His demonstration has a typological argument at its heart: Christian exegesis considers the anthropomorphic descriptions of God by the prophets of the Old Testament to be prefigurations of the incarnation of the Word. Therefore, before the incarnation these descriptions are authentic "images" of the eternal model. In the same way, icons and saints are "images" of the model after the incarnation. ${ }^{98}$ This equivalence is based on a metaphorical conception of language, perhaps inspired by the Peri hermeneias: Abu Qurra says that names and "images" (șuwar), have the same signifying function ${ }^{99}$ - in fact:

written names are symbols (ashbāh) and images (așnām) of sounds (alfāz), and these latter are symbols of imagined figures (ashbāh al-awhäm), and these imaginations (awhām) are symbols of things (ashbāh al-ashy $\bar{a})$, as the falsafa [var.: al-falāsifa] affirm. ${ }^{100}$

By the term șūra Abū Qurra indicates at once the "types" of Christ in the Old Testament and icons. Indeed, in Greek, eikon is often used as a synonym for typos, and Latin retains this synonymy, translating typos as figura. ${ }^{101}$ According to Frances Young, the exegesis of the school of Antioch should be called "iconic" rather than "typological", in order to highlight the fact that it does

97 Compare the quotation from Jāhịiz in Corbin, Limagination créatrice, 205 and 275, note 323; see also Holtzman, "Anthropomorphism", 53b.

98 Abuqurra, Traité, Ch. 5, 11, 21. Abū Qurra refers in particular to the vision of the throne of Ezekiel (5: 12;11: 30-37), which has fed both Christian and Jewish mysticism. This vision is recalled in the Kitāa al-Zuhd by Ahmad ibn Hanbal, in a tradition by Wahb ibn Munabbih, according to which God says to Ezekiel: "The fearful and tender heart of the believer contains me" (wasi'anī qalb al-mu'min al-wāric al-layyin). See https://library.tebyan.net/fa/ Viewer/Text/136381/8o (text online from Qom edition: Mu’assasat tibyān, 1387).

99 Abuqurra, Traité, Ch. 12, 2.

100 Abuqurra, Traité, Ch. 12, 18. Compare Aristote, De l'interprétation 1 (16a), trans. Tricot, 78-79.

101 Young, Biblical Exegesis, 192. 
not limit itself to establishing correspondences between the Old and the New Testaments, but constitutes a hermeneutic key to revelation and nature: the "contemplation" (theoria) that it encourages is distinguished from Alexandrine allegorism because it focuses on singular examples rather than on philosophical concepts. ${ }^{102}$ What's more, Abū Qurra's treatise demonstrates how this iconic or figural approach relates to hagiography. The way he conceives the "presence" of the archetype in the prophets and saints is very close to the Prophetic model of sainthood in Islam, in which the "reality" of Muhammad is the source of sainthood, and is reflected in the prophets who preceded his full earthly manifestation and in the saints that came after it. ${ }^{103}$ On the one hand, this concept implies that earlier prophets retain an exemplary function for saints, and on the other that the advent of the "supreme form" (șüra 'azìma) $)^{104}$ of God does not bring the believer's personal relationship with God to an end, but rather reinforces it by mediating it.

It is true that Nābulusī, in a mawlid, says of Muhammad: "he destroys churches, synagogues, hermitages, and abrogates all other laws". ${ }^{105}$ But elsewhere he specifies that even if Muhammad has abrogated all other religions, "he only abrogated them with respect to legal acts. As for professions of faith, he did not use abrogation on them". ${ }^{106}$ This passage occurs within a commentary on a poem by the Andalusian Sufi Shushtarī (d. 668/1269), in which Nābulusî justifies the use of Christian symbols and terms in Sufi poetry; icons are notable among the symbols he mentions. In the introduction to this treatise, he synthesises the ideas laid out by Ibn 'Arabī in Chapter 36 of the Futühăt, about the Muslim saints who follow Jesus's model ('isāwiyyūn). This chapter contains a passage on the "doctrine of images" (al-qawl bi-l-șurra), the importance of which has been revealed in detail by Michel Chodkiewicz. ${ }^{107}$ In a commentary on Shushtarīs verse "They shall give thee the key of the church in which their monks have painted Jesus figuratively" (wa-ațawka miftăha al-kanisati wa-llatī - biha șawwarat 'T̃ā rahābinuhum shaklan) Nābulusī tackles the subject:

They shall make thee understand the images in which divine reality is made manifest to them in their spirits (afhamūka al-șuwar allatī fi nufüsihim tazhar lahum fìna al-haqiqqa al-ilähiyya): they declared its

\footnotetext{
102 Young, Biblical Exegesis, 192-201.

103 Chodkiewicz, "Le modèle prophétique".

104 Compare Nābulusī, Jawāhir, 308.

105 Nabhānī, Faḍ̄ìil, 1063.

106 Urvoy, "Les thèmes chrétiens", 108; Nābulusī, Radd, 632-633.

107 Chodkiewicz, Sceau, 97-98. See further: Abdel-Hadi, "Unexplored Concepts".
} 
transcendence (yunazzihūnahā) by virtue (bi-hukm) of "There is nothing that resembles Him" (Q 42:11), and they declare its resemblance (yushabbihünahā) by virtue of "And He is the hearer, the clairvoyant" (Q 42:11). This is similitude according to the Law (al-tashbih al-shar $\bar{\imath}$ ), that which brings the meaning that God [alone] knows (alladhi warada bi-l-ma'nà alladhi yalamuhu Allāh). For on this subject He has said that He has one face, by his own Word: "Wherever thou turnest, the face of God is still there" (Q 2:115), and that He has one hand, by his own word: "The hand of God is above their hands" (Q 48:10), and other, similar, expressions, whereas, in all this, declaring His transcendence (tanzih $)$ is necessary. Comparable ambiguous (mutashābih) expressions can be found in the Gospels. ${ }^{108}$

In other words, the "key" to understanding icons is the symbolic exegesis of the Qur'an's verses on "resemblance". Through this equivalence between the veneration of icons and the contemplation of the figurative expressions in the Qur'ān, Nābulusī offers an Islamic "translation" of Christian spiritual practice. At the same time, this passage presents striking similarities to Abū Qurra's treatise. First comes the fairly exact correspondence of Nābulusî's commentary with Chapter Five of this treatise. In the modern edition this is entitled "The bodily attributes of God that are found among Muslims must bring them to understand what we aver on the subject of Christ."109 Here Abū Qurra alludes specifically to the Qur'ānic verses on "resemblance" that Nābulusī mentions: "The non-Jew who claims to be a believer [that is to say the Muslim] will say: I don't accept any of these things! Nevertheless, he asserts that God is seated on the throne, and that He has a face and a hand, and other things that we don't have space to mention here."110

The second similarity is in the polemical aim of both texts: Abū Qurra refutes the objections of outsiders (barrāniyyūn), meaning Jews and Muslims, but is also proposing to help Christians who are turning away from icons under the influence of the criticism of outsiders to return to the right path. Thus he reminds his Christian readers that what really differentiates Christians from followers of other religions is the spiritual intelligence of the Scriptures, which he contrasts with "carnal intellect" (al-'aql al-jasadānī). ${ }^{11}$

\footnotetext{
108 Nābulusī, Radd, 636.

109 Abuqurra, Traité, 106: mā jā̉a ladā al-muslimīn min awșāf mujassima li-Allāh yajib an tuqarrib lahum fahm mā naqūluhu fì al-masīh.

110 Abuqurra, Traité, Ch. 5, 16; see also Ch. 9, 35-37, where the prosternation of angels before Adam, Q 2:30, is discussed.

111 Abuqurra, Traité, Ch. 5, 4; see also Ch. 18, 18-19.
} 
As for Nābulusī, he refutes the objections of exoteric Muslims to the poetry of poet-saint 'isawì-muhammadì Shushtarī, by explaining that the Christian practices of which he speaks (the cult of images is the one that interests us here) do not make their followers infidels (kuffär) if one understands their authentic meaning. Those gifted to understand these authentic meanings are spiritual masters (rabbāniyyūn), and as such are distinct from those who are dominated by their carnal soul (nafsāniyyūn). This distinction also applies to Christians, so that the rabbāniyyūn among them are not, in fact, infidels (kuffär), unlike their nafsāniyyūn. ${ }^{12}$ From this we can deduce that the Christian rabbāniyyūn may also themselves be a source of "correct" intelligence on the cult of images. It is therefore possible that Nābulusī was familiar not only with Ibn 'Arabī's approach to "the doctrine of images", but also with the Christian sources themselves.

Here Nābulusī also introduces interesting thoughts on the expression of Christian concepts in the Arabic language: given that each prophet speaks the language of his own people, and that the language of Jesus was Syriac, the Arabisation of Syriac words is not enough to make them understandable in the language of Muhammad. Thus, a poet such as Shushtarī, who draws his inspiration from the haqiqa ìsāwiyya-muhammadiyya, speaks in Arabic, but in the "Syriac tongue" (lisān suryānī), in other words, unclearly (ghayr mutabayyin al-ma'nā). What's more, in the Sufi lexicon, Suryāniyya means a language understood by saints and unintelligible to others; Nâbulusī plays on both senses. In the same way, the translation of the Gospels into Arabic, and the creation of an Arab-Christian lexicon (iștilăhn) remain in "Syriac" unless one also translates them conceptually, by explaining how they correspond to "secrets" and spiritual stages for insightful Muslims. ${ }^{113}$ For example, in "Muhammadan" Arabic the Messiah corresponds to the Spirit and Mary to the Well-Preserved Tablet. ${ }^{114}$ The inverse operation is also possible: for example, when a 'is $\bar{a} \bar{w} \bar{\imath}-$ muhammadi saint reads the Qurānic verse 19:34, its "Syriac" meaning becomes apparent, which probably means that this verse will be understood to say "This is Jesus, the son of Mary, the Word of Truth about whom they doubt", rather than "Such was Jesus, son of Mary: (this is) a statement of the truth concerning which they doubt". 115

\footnotetext{
112 Nābulusī, Radd, 63: al-nașārā alladhīna kafarū kānū nafsāniyyīn lā rabbāniyyīn.

113 Nābulusī, Radd, $63^{2}$.

114 Nābulusī, Radd, 637 .

115 Nābulusī, Radd, 633-34: wa-qāla ta'ālā: "dhālika 'T̄sā ibnu Maryama qawl al-haqqq alladhī fìhi yamtarūn" [Q 19:34]: fa-akhbara subḥānahu anna al-imtirā̄ ḥạșil fì hādhihi al-kalima al-suryāniyya al- ìsāwiyya fa-idhā takallama bihā al-muhammadì min al-mashrab al-'̄̄sāwō zaharat suryāniyya kamā kānat li-annahu táālā lā mubaddila li-kalimātihi.
} 
It is likely that these considerations were prompted by events in Christian culture during the seventeenth and eighteenth centuries, when Arabic was confirmed as the liturgical language of most Arabic-speaking Christians in Syria. ${ }^{116}$ The Arabisation of the liturgy was accompanied by an increased tendency to translate the classical languages of Levantine Christians - Greek, Syriac, and Armenian, as well as Latin, under Rome's influence - into Arabic; Arabic linguistic and literary traditions were also re-appropriated and adapted for a Christian public.

As Hilary Kilpatrick notes, literary history has neglected to place the renaissance in Christian literature that occurred during this period in the context of contemporary Arabo-Muslim culture; thus we lose sight of the role played by the intellectual exchanges and aesthetic syntony between Christians and local Muslims. ${ }^{117}$ A verse by Germanus Farhạat (1670-1732) on the Virgin Mary, "Faultless pearl, thou wert created - as though according to thine own desire thou wert created" (khuliqti durratan lā 'ayba fih ā - ka'annaki mithlamā shi'ti khuliqti), ${ }^{118}$ that appears to take as its model the prototypical madīh nabawi, the poem by Ḥassān ibn Thābit (khuliqta mubarra'an min kull 'aybin-ka'annaka khuliqta kamā shita), demonstrates the relevance of Nābulusîs reflections on the relationship between "Muhammadan" Arabic and "Christian" Arabic.

Nābulusī maintained a theological correspondence with a Christian dignitary whom we can probably identify as Athanasius Dabbās (d. 1136/1724). He was the Melikite patriarch of Antioch, and one of the protagonists of the cultural renewal among Syria's Christians. He translated patristic works by John Chrysostom and Basil of Caesarea from Greek to Arabic, and founded the first printing house in Aleppo to use Arabic characters. ${ }^{119}$ At the beginning of his epistle, Nābulusĩ addresses his correspondent as "one of the brothers of spiritual detachment" (ikhwān al-tajrìd). ${ }^{120}$ The dhimmis who had the gift of inner faith (al-imān bätinan) were also "brothers", in a treatise in which Nābulusī takes up and amplifies a short passage in the Futūhăat, from the chapter on the isawìy

\footnotetext{
116 Kilpatrick, "From Literatur to Adab", 203.

117 Kilpatrick, "From Literatur to Adab", 203; for example, in the library of a Lebanese monastery there was a glossed copy of Ibn al-Fāriḍ's Dīwān: Walbiner, "Monastic", 473.

118 Ayoub, "L'hyperbole", 17.

119 Aladdin, "Deux fatwā-s"; Rafeq, "Religious Tolerance”, 7. On the translations, see Graf, Geschichte, 3: 127-133.

120 Aladdin, "Deux fatwā-s", 9 (French), 22 (Arabic).

121 Nābulusī, $Q a w l$, 216a: the dhimmīs who believe inwardly pay the jizya "to help their Muslim brothers" (iānatan li-al-muslimin min ikhwānihim). Lejla Demiri is preparing a critical edition of this text.
} 
'Arabì suggests that the people of the Book who submit to the jizya will go to paradise. ${ }^{122}$ Nābulusī defends this idea, arguing that God has no obligation to put his threats into practice; he supplements this theological reasoning with a linguistic argument: he contests the authority of his anonymous adversary, whom he derisively calls "Turk", to interpret the Qurān, maintaining that he is incapable of understanding the spirit of the Arabic language, whereas Ibn 'Arabì and the Arab 'ulam $\bar{a}$ ' whom he inspires do, on the contrary, understand it perfectly. The Arabic language has always been the inner language of revelation (wahy), ${ }^{123}$ exteriorised with the advent of Muhammad, the prophet of compassion $(\mathrm{rahma})$. It is not sufficient to know the rules of its grammar in order to master it; one must have a natural disposition and spontaneity (țabĩ $a$ and salīqa): this is why an illiterate Arab is considered more noble than an erudite non-Arab $(a j a m \bar{\imath}) .{ }^{124}$ In spite of their extensive study, most foreigners must make huge and painful efforts in order to speak Arabic. Even worse is to be "a non-Arab at heart" (ajamīal-qalb), ${ }^{125}$ to lack the ear to speak in the accents of mercy in the language of revelation.

In other words, the approach of the "Turk" or "non-Arab at heart" to the Arabic language and the Qur'ān is one of strict normativity, both grammatical and Islamic. People whose mother tongue is Arabic, even if they are illiterate and/or not Muslims, are closer to the matrix from which the language sprang. In this respect the original version of Germanus Farhāt's Arabic dictionary is suggestive in containing two long explanations of the expressions al-rahma al-jasadiyya (physical compassion) and al-raḥma al-rūhiyya (spiritual compassion); these were substantially abridged by the dictionary's modern editor, who judged them to be based on Christian doctrine rather than on the study of the language itself. ${ }^{126}$ However, spirituality before the nahda was not formally divided from adab, and Nābulusî's œuvre demonstrates how it can function as a component of a shared conceptual syntax.

\footnotetext{
122 Chodkiewicz, Sceau, 101.

123 Nābulusī, Qawl, 58a.

124 Nābulusī, Qawl, 63a.

125 Nābulusī, Qawl, 84a. Conversely, a saint who can't speak Arabic is "Arab in spirit" when he speaks in his own language under inspiration, as Nābulusī says explaining the saying: "I slept as a Kurd and woke up as an Arab", attributed to an illiterate shaykh admired by Jalāl al-Dīn Rūmī: See Sukkar, "al-Nābulusî", 155.

126 Kilpatrick, "From Literatur to Adab", 208.
} 
In conclusion, for Nābulusī, celebrating and glorifying the Prophet means celebrating Sufis, celebrating Arabs ${ }^{127}$ and, especially, celebrating Arabic literary culture. ${ }^{128}$ And being "like the Prophet" means being an "author". His exaltation of his own literary production in prose or verse, and in all genres, is not, despite his work's importance for the city, associated with leadership ambitions, or the foundation of a tariqa, but with his aim to persuade and educate his readers both profane and specialist - both aesthetically and spiritually. ${ }^{129}$ In his image of himself, the eclecticism of the accomplished man of letters is part of the universalism of the perfect man. ${ }^{130}$ At the same time, his reflections on the space in religious life for imaginative representation mean that Muhammad becomes not only the object of poetical, visual and musical production, but also (in a way) the patron of these expressions that are as devotional as they are artistic. Nābulusī's reflections on God's manifestation in human language and human form are at the heart of his concept of Muhammad's "reality"; they also carry unmistakeable marks of his familiarity with the Christian culture of the Syrian people, and of his concern to "translate" religious symbols in order to encourage intellectual and emotional exchange with Christian Arabs.

Nabhānī admires Nābulusī very much, but he differs from him on some of the latter's most characteristic attitudes. For example, he prefers, in the madih nabawi, to set very narrow limits on the use of the ghazal (especially those addressed to young men). ${ }^{131} \mathrm{He}$ also takes care to distinguish the veneration of Muhammad from that practised by Shīīs and Christians, since one must ultimately avoid confusing poetic hyperbole with dogma. ${ }^{132}$ Finally, although he had 40 ,ooo copies of an engraving of the Prophet's Sandal printed ${ }^{133}$ (mechanical reproduction had by now brought an end to the time when each copy was a unique exemplar, an "original"), he also wrote a pamphlet against images. ${ }^{134}$ This text, published in 1906, illustrates the profound cultural rupture that had

127 See his exaltation of the Arab qabāill in a mawlid improvised for the people of Nābulus: Nābulusī, Haqīqa, 106-107.

128 In another mawlid, he celebrates as blessings from God a lengthy series of books that "flows" from the prophetic source, starting with the Futūhät. Yet the series also includes a book in Persian, the Mathnawì by Rūmī. See Nabhānī, Faḍāil, 106o-64. On Nābulusì's commentary on the Arabic preface to the Mathnawī, see Sukkar, "al-Nābulusī", ${ }^{2-}{ }^{26}$.

129 Nābulusī, Dīwān al-haqā̄iq, 1, 6, 16.

130 Nābulusī, Dīwān al-ḥaqū̉iq, 1, 11-12; 2, 24.

131 Nabhānī, al-Majmū'a al-Nabhāniyya, 14, 24-31.

132 Nabhānī, Faḍ̂̉ill, 1 and 3.

133 Nabhānī, Faḍ̄ìl, 931, 972, 975-76.

134 Nabhānī, Taḥdhīr. 
occurred since the time of Nābulusì. When speaking of images, Nābulusī drew on the classical heritage of the Near East, whereas this seems to have disappeared from Nabhānīs points of reference. In what may be a reaction to a 1903 text by Muhammad 'Abduh, in which the Egyptian Mufti celebrates European painting while implying a critique of the cult of saints as potentially being "idolatry" (shirk), ${ }^{135}$ Nabhānī can find no better response than to attack the idolatry of Christians, expressing his disapproval of both religious and secular images. The supposedly "historic" critique, in which he describes Christian adoration of images as a survival of paganism, and his reference to Protestant criticism of this "innovation", lead one to speculate that he may have been influenced by a book written by the American pastor Benjamin Schneider (1834-77), who was then living in Aintab with the aim of encouraging the Armenians who populated the region at the time to return to the straight path. ${ }^{136}$

And yet Nabhāni makes an exception for the shadow theatre, praising the beauty of an anonymous couplet that alludes to the teachings contained in this form of spectacle. ${ }^{137}$ Despite his scruples on the subject of the ghazal, Nabhānī finally decides not to exclude them from his collection of madāih because:

Considering that this is present in a great many admirable poems, my soul did not permit me to deprive this collection of such well-aligned pearls, and to deprive these excellent poets of such a noble station and such immense merit, for, if they have erred, they have nevertheless also done right in praising the Prophet, and only God can know their intentions. ${ }^{138}$

\section{Bibliography}

\section{Primary Sources}

'Abduh, M. al-A'māl al-kāmila, ed. M. 'Imāra, Vol. 2, Cairo, Dār al-shurūq, 1414/1993. Abuqurra, Th. Traité du culte des icônes, Introduction and critical text by Ignace Dick. Rome, Pontificio Istituto Orientale, 1986.

\footnotetext{
135 'Abduh, A'māl, 2, 198-200.

136 Schneider, Rayhana. This book is still honoured in a recent publication on the correct way of imitating the Prophet: Hāamid, Muqaddimāt, 116-40.

137 Nabhānī, Tahdhīr, 1: ra'aytu khayāla al-zilli akbara 'ibratin - li-man kāna fì 'ilmi l-ḥaqüqati rāqū / shukhūṣun wa-ashbāḥun tamurru wa-tanqaḍ̄ - wa-tanfā jamīan wa-l-muharriku $b \bar{a} q \bar{q}$. Nābulusī wrote an imitation of these verses: see Dìwan al-ḩaqā̉iq, 1, 341.

138 Nabhānī, al-Majmū'a al-Nabhāniyya, 14-15.
} 
Aqhịisārī, A. Majālis al-abrār wa masālik al-akhyār, Arabic text with interlinear Urdu translation in Subhān Bakhsh al-Shikārpūrī, Khazīnat al-asrār, tarjamat Majālis al-abrār, Delhi, Mațba' Mușțafā'ī' 1283/1866.

Aristote. De l'interprétation, in Aristote, Organon. I Catégories. II De l'interprétation, trans. J. Tricot. Paris, Vrin, 1984.

Averroès (Ibn Rushd). Commentaire moyen à la Rhétorique d'Aristote, Introduction générale, Critical edition of the Arabic text; French translation, commentary and tables by M. Aouad, 2 vols., Paris, Vrin, 2002.

Baytamānī, Ḥ. b. Ṭ. al-. Kashf al-asrār fi 'ulūm al-mustafāda min khayāl al-izār, Ms Damascus, Zāhiriyya, 111268, ff. 181-289.

Ghazzī, K. al-Wird al-unsī wa-l-wārid al-qudsī fì tarjamat al-ārif 'Abd al-Ghan̄̄ al-Nābulusī, ed. S. Akkach, in Intimate Invocations. Al-Ghazzī's Biography of 'Abd al-Ghanī al-Nabulusī (1641-1731), Leiden, Brill, 2012.

Ḥāmid H. Muqaddimāt fì 'ilm al-ittibā': qirā’a naqdiyya istiqrāìyya fì mafhūm al-bid'a, Riyadh, 2016.

Ibn 'Arabī, M. Al-Futūḥāt al-makkiyya, 4 vols., Cairo 1329/[1911], repr. Beirut [1968].

Ibn Hajar al-Haytamī. Ashraf al-wasāil ilā fahm al-shamāill, Beirut, Dār al-kutub al-ilmiyya, 1419/1998.

Muslim, Sahîh, English trans. N. al-Khattab, Riyadh, Darussalam, 2007.

Nabhān̄̄, Y. al-Majmū'a al-Nabhāniyya fì al-Madāiḥ al-Nabawiyya, 4 vols., Beirut, Dār al-fikr, n.d. [First edition, Beirut, al-Mațba'a al-Adabiyya, 1903].

Nabhānī, Y.Jawāhir al-biḥār fìfaụāil al-nabīal-mukhtār, Beirut, al-Maṭba'a al-adabiyya, 1325-27 [1907-1909].

Nabhānī, Y. al-Taḥdhīr min ittikhādh al-ṣuwar wa l-tașwìr, no location, 1324 (19o6), text online: http://dar.bibalex.org/webpages/mainpage.jsf?PID=DAF-Job:64789.

Nābulusī, 'A. Dīwān al-ḥaqā̉iq wa-majmū' al-raqā’iq, Cairo, Maṭba'at Bulaq, 1270/1854 (reprint Beirut, Dār al-Jīl. n.d.).

Nābulusī, 'A. al-Hạ̣ra al-unsiyya fi al-rịhla al-qudsiyya, ed. A. Ḥ. al-'Ulabī, Beirut, al-Mașādir, 1990.

Nābulusī, 'A. al-Ḥāmil fì al-falak wa l-maḥmūl fı al-fulk fì iṭlāq al-nubuwwa wa l-risāla wa-al-khilāfa wa l-mulk, ed. S. Pagani, in L. Demiri and S. Pagani eds., Early Modern Trends in Islamic Theology. 'Abd al-Ghanī al-Näbulusī and His Network of Scholarship (Studies and Texts), Tübingen, Mohr Siebeck, 2019, 327-362.

Nābulusī, 'A. al-Haqūqa wa-l-majāz fì al-riḥla ilā bilād al-Shām wa-Miṣrwa l-Hịjāz, Cairo, al-Hay’a al-Miṣriyya al-Āmma li-al-Kitāb, 1988.

Nābulusī, 'A. Izālat al-khafā' 'an Hilyat al-Muștafā, ms. King Saud University 19o6, ff. 1-8 (https://al-mostafa.info/data/arabic/depot/gap.php?file=mo10444.pdf).

Nābulusī, 'A. Jawāhir al-nuṣūṣ fì hall kalimāt al-Fuṣūṣ, Cairo, Maṭba'at al-Zamān, al-Mațba‘a al-'̄̄mira, 1323 AH (1905). 
Nābulusī, 'A. Kashf al-sirr al-ghāmiḍ fi sharh dīwān Ibn al-Fārị̣, ed. Kh. al-Zar'ī, Damascus, Dār Nīnawā, 1438/2017.

Nābulusī, 'A. Nafḥat al-qabūl fì madḥ al-rasūl, ed. F. N. 'A. Ḥusayn, Cairo, Dār al-fikr al-'arabī, 1420/1999.

Nābulusī, 'A. Natījat al-'ulūm wa nașịhat 'ulamā̄' al-rusūm, ed. and trans. S. Pagani in Il rinnovamento mistico dell'Islam. Un commento di 'Abd al-Gani al-Nabulusi a Ahmad Sirhindi, Naples, Istituto Universitario Orientale, 2003.

Nābulusī, 'A. al-Qawl al-sadìd fì jawāz khulf al-waìd, ms. Damascus Zāhiriyya 1418, ff. $53 \mathrm{~b}-100 \mathrm{~b}$.

Nābulusī, 'A. Radd al-muftarī 'an al-ța'n fì al-Shushtarī, ed. A. 'A. Khalīfa, al-Mashriq 54 (1960), 629-639.

Nābulusī, 'A. Risāla fì al-kashf 'an țarīq al-wilāya, ms. Damascus Zāhiriyya 4008, ff. $12 \mathrm{a}-15 \mathrm{~b}$.

Nābulusī, 'A. al-'Uqūd al-lu’lu'iyya fì țarīq al-sāda al-mawlawiyya, Damascus: Maṭba'at al-taraqqī, 1350/1932

Nābulusī, 'A. Ta'țīr al-anām fì ta'bìr al-manām, Cairo, (n. p.), 1929.

Nābulusī, 'A. Wird al-wurūd wa fayd al-bahr al-mawrūd, ms. Tokyo, Institute of Oriental Studies, 335 [1762], ff. 1-109 (http://ricasdb.ioc.u-tokyo.ac.jp/daiber/db_ShowImg_I .php?vol $=1 \& \mathrm{~ms}=335 \&$ txtno $=)$.

Schneider, B. Rayḥānat al-nufūs fì aṣl al-ítiqadāt wa-l-țuqūs: History of Ceremonies, Beirut, 1889 .

\section{Secondary Literature}

Abdel-Hadi, F. "Unexplored Concepts. Rahbāniyya as sagehood", Journal of the Muhyiddin Ibn 'Arabi Society 61 (2017), 43-78.

Addas, Cl. "Le vaisseau de pierre", Journal of the Muhyiddin Ibn 'Arabi Society 19 (1996), consulted online at this address http://www.ibnarabisociety.org/articles/vaisseau .html.

Aladdin, B. "Abd al-Ġanī an-Nābulusī (1143/1731). CEuvre, vie et doctrine", 2 vols, PhD diss., University of Paris-Sorbonne, 1985.

Aladdin, B. "Deux fatwā-s du Šayh 'Abd al-Ġanī al-Nābulusī (1143/1731): présentation et édition critique", Bulletin d'Études Orientales, 39-40 (1987-1988), 7-36.

Aladdin, B. "'Abd al-Ghanī al-Nābulusī, the Doctrine of Unity of Being and the Beginnings of the Arab Renaissance", in L. Demiri and S. Pagani (eds.), Early Modern Trends in Islamic Theology. 'Abd al-Ghani al-Näbulusī and His Network of Scholarship (Studies and Texts), Tübingen, Mohr Siebeck, 2019, 31-48.

Arendt, H. "What is Authority?", in Between Past and Future. New York, Viking Press, 1961, 91-143. 
Ayoub, G. "L'hyperbole dans la poésie amoureuse du mannā", Revue Langues, cultures et sociétés $5 / 2$ (2019), $5^{-24}$.

Balic S. Das unbekannte Bosnien, Europas Brucke zur islamischen Welt, Köln, Böhlau Verlag, 1992.

Bashier, S. H. Ibn al-'Arabis Barzakh. The Concept of the Limit and the Relationship between God and the World. New York, State University of New York Press, 2004.

Bettetini, M. Contro le immagini. Le radici dell'iconoclastia. Bari, Laterza, 2006.

Brague, R. La loi de Dieu. Histoire philosophique d'une alliance, Paris, Gallimard, 2005.

Cachia, P. The Arch Rhetorician, or The Schemer's Skimmer: A Handbook of Late Arabic "badī”" drawn from 'Abd al-Ghanīal-Nābulsı̀s "Nafahàt al-azhār 'alā Nasamāt al-ashāar", Wiesbaden, Harrassowitz, 1998.

Camplani, A. "Il dibattito sulla visione di Dio e sull' 'uomo ad immagine' nel monachesimo egiziano: interpolazioni e riscritture nei testi copti attribuiti ad Agatonico di Tarso", in I. Adinolfi, G. Gaeta, A. Lavagetto, eds. Anti-Babele. Sulla mistica degli antichi e dei moderni, 149-184. Genova, Il Melangolo, 2017.

Chodkiewicz, M. Le Sceau des saints. Prophétie et sainteté dans la doctrine d'Ibn Arabī, Paris, Gallimard, 1986.

Chodkiewicz, M. Un Océan sans rivages. Ibn Arabī, le Livre et la Loi, Paris, Seuil, 1992.

Chodkiewicz, M. "Le modèle prophétique de la sainteté en islam," Al-Masāq: Islam and the Medieval Mediterranean 7 (1994), 201-226.

Corbin, H. L'imagination créatrice dans le soufisme d'Ibn 'Arabi, Paris, Flammarion, 1958.

Corbin, H. Corps spirituel et terre céleste. De l'Iran mazdéen à l'Iran shîite, Paris, Buchet-Chastel, 1979 (English translation Spiritual Body and Celestial Earth. From Mazdean Iran to Shïite Iran, trans. Nancy Pearson, Princeton: Princeton University Press, 1977).

Del Cogliano, M. “Situating Sarapion's Sorrow: The anthropomorphite Controversy as the Historical and Theological Context of Cassian's Tenth Conference on Pure Prayer", Cistercian Studies Quarterly 38/4 (2003), 377-421.

Dreher, J. "Une polémique à Istanbul au XVII e siècle. Les parents du Prophète étaientils musulmans?", in R. Chih and C. Mayeur-Jaouen eds. Le soufisme à l'époque ottomane, XVI ${ }^{e}-X V I I I^{e}$ siècle / Sufism in the Ottoman Era, 16th-18th Century, 291-307. Cairo, Institut Français d'Archéologie Orientale, 2010, 291-307.

Florensky, P. Iconostasis, trans. D. Sheehan and O. Andrejev, Crestwood, New York, St Vladimir's Seminary Press, 1996.

Graf, G. Geschichte der christlichen arabischen Literatur. Vol. 3, Die Schriftsteller von der Mitte des 15. Bis zum Ende des 19. Jahrhunderts: Melchiten, Maroniten, Città del Vaticano: Biblioteca Apostolica Vaticana, 1949.

Gril, D. “Jawāhir al-nuṣūṣ fì ḥall kalimāt al-Fuṣūṣ: 'Abd al-Ghanī al-Nābulusīs Commentary on Ibn 'Arabī’s Fuṣūṣ al-ḥikam”, in L. Demiri and S. Pagani eds. Early Modern 
Trends in Islamic Theology. 'Abd al-Ghanī al-Nābulusī and His Network of Scholarship (Studies and Texts). Tübingen, Mohr Siebeck, 2019, 49-57.

Grondin, J. Introduction to philosophical hermeneutics, trans. J. Weinsheimer, Yale University Press, 1994.

Gruber, C. "Between logos (kalima) and light (nür): representations of the Prophet Muhammad in Islamic painting”, Muqarnas 26 (2009), 229-62.

Gruendler, B. "Fantastic Aesthetics and Practical Criticism in Ninth-Century Baghdad", in G. van Gelder and M. Hammond eds. Takhyil: The Imaginary in Classical Arabic Poetics, Exeter, E. J. Gibb Memorial Trust, 2009, 196-220.

El-Rouayheb, Kh. Islamic Intellectual History in the Seventeenth Century. Scholarly Currents in the Ottoman Empire and the Maghreb, Cambridge University Press, 2015, 262-64, 285-94.

Heinrichs, W. "Introduction", in G. van Gelder and M. Hammond eds. Takhyil: The Imaginary in Classical Arabic Poetics, Exeter, E. J. Gibb Memorial Trust, 2009, 1-14.

Heyberger, B. "Entre Byzance et Rome: l'image et le sacré au Proche-Orient au XVII' siècle", Histoire, économie et société 8-4 (1989), 527-50.

Hirtenstein, St. The Unlimited Mercifier, 1999, Oxford, Anqa Publishing.

Holtzman, L. “Anthropomorphism”, in K. Fleet, G. Krämer, D. Matringe, J. Nawas, E. Rowson eds. Encyclopaedia of Islam, THREE, Leiden-Boston, Brill, 2011, 46-55.

Homerin, Th. E. “'On the Battleground': Al-Nābulusî’s Encounters with a Poem by Ibn al-Fārị̣", Journal of Arabic Literature 38 (2007), 352-410.

Jokisch, B. Islamic Imperial Law. Berlin, de Gruyter, 2007.

Holmes Katz, M. The Birth of the Prophet Muhammad: Devotional piety in Sunni Islam, London-New York, Routledge, 2007.

Kilpatrick, H. "From Literatur to Adab: the literary renaissance in Aleppo around 1700", Journal of Eastern Christian Studies $5^{8}$ (2004), 195-220.

Leaman, O. An Introduction to Classical Islamic Philosophy, Cambridge University Press, 2002.

Lizzini, O. “Introduction. Le langage de Dieu: révélation et prophétie chez Avicenne”, in Avicenne, Epître sur les prophéties, trans. J.-B. Brenet, Paris, Vrin, 2018, 7-82.

López Anguita, G. “'Abd al-Ganī al-Nābulusī (m. 1143 H. / 1731 d. C.): La 'riḥla' másallá de las convenciones del género", Philologia Hispaliensis 31/2 (2017), text online https:// revistascientificas.us.es/index.php/PH/article/view/3352/4775.

Lory, P. Le rêve et ses interprétation en Islam, Paris, Albin Michel, 2003.

Māliḥ, Riyāḍ al-. Fihris makhțūṭāt al-Zāhiriyya. Tașawwuf, Damascus, Maṭba'at al-Hijāz, vol. 2, 1398/1978.

Michot, J. R. La destinée de l'homme selon Avicenne. Le retour à Dieu (ma'ād) et l'imagination, Louvain, Peeters, 1986.

Michot, Y. Against Smoking. An Ottoman Manifesto, Oxford, Interface Publications, 2010. 
Nicholson, R. A. Studies in Islamic Mysticism, London, Routledge Curzon, 2003 (first edition 1921).

Pagani, S. "Défendre le soufisme par des temps difficiles: 'Abd al-Ghani al-Nabulusi, polémiste anti-puritain", in R. Chih, D. Gril, C. Mayeur-Jaouen, eds., Le soufisme en Egypte et dans le monde musulman à l'époque ottomane, Cairo, Institut Français d'Archéologie Orientale, 2010, 309-335.

Puerta Vílchez, J. M. Aesthetics in Arabic Thought. From Pre-Islamic Arabia through alAndalus, Leiden, Brill, 2017.

Rafeq, A-K. "Abd al-Ghani al-Nabulsi. Religious Tolerance and 'Arabness' in Ottoman Damascus", in C. Mansour and L. Fawaz, eds. Transformed Landscapes. Essays on Palestine and the Middle East in Honor of Walid Khalidi, Cairo, American University in Cairo Press, 2009, 1-17.

Rosenthal, F. "Ibn 'Arabī between 'philosophy' and 'mysticism”, Oriens 31 (1988), 1-35.

Scattolin, G. "The Key Concepts of al-Farghānī's Commentary on Ibn al-Fāriḍ's Sufi Poem, al-Tā'iyyat al-Kubrā", Journal of the Muhyiddin Ibn 'Arabi Society 39 (2006), $33-83$.

Stetkevych Pinckney S. The Mantle Odes. Arabic Praise Poems to the Prophet Muhammad. Bloomington, Indiana University Press, 2010.

Sukkar, A. "Abd al-Ghanī al-Nābulusī of Damascus (d. 1143/1731) and the Mawlawī Sufi Tradition", Mawlana Rumi Review 5 (2014), 136-170.

Urvoy, D. and Urvoy, M.-Th. "Les thèmes chrétiens chez Ibn Sab'īn et la question de la spécificité de sa pensée", Studia Islamica 44 (1976), 99-121.

Vadet, J.-Cl. L'esprit courtois en Orient dans les cinq premiers siècles de l'Hégire. Paris, Maisonneuve et Larose, 1968.

Voll, J. "'Abd al-Ghanī al-Nābulusī and Abū l-Mawāhib al-Hanbalī: Scholarly Networking in Damascus and Beyond", in L. Demiri and S. Pagani eds. Early Modern Trends in Islamic Theology. 'Abd al-Ghanī al-Nābulusī and His Network of Scholarship, Tübingen, Mohr Siebeck, 2019, 195-210.

Walbiner, C. "Monastic Reading and Learning in Eighteenth-Century Bilād al-Šām: Some Evidence from the Monastery of al-Šuwayr (Mount Lebanon)", Arabica 51.4 (2004), 462-477.

Weiss, B. G. The Search for God's Law: Islamic Jurisprudence in the Writings of Sayf al-Din al-Āmidī, Salt Lake City, University of Utah Press, 2010.

Williams, W. "A Body Unlike Bodies: Transcendent Anthropomorphism in Ancient Semitic Tradition and Early Islam", Journal of the American Oriental Society 129/1 (2009), 19-44.

Young, F. M. Biblical Exegesis and the Formation of Christian Culture. Cambridge University Press, 1997. 